\title{
Barriers to Implementing ITIL-A Multi-Case Study on the Service-based Industry
}

\author{
Shari S. C. Shang \\ National Chengchi University \\ E-Mail: sshang@nccu.edu.tw \\ Shu-Fang Lin \\ Yuanpei University \\ E-Mail: lucy_linn@yahoo.com
}

\begin{abstract}
This paper reports the findings of a multi-case study on three service-based companies. It intends to highlight the difficulties that the customer service centers of these companies had in their attempt to implement IT infrastructure library to improve organizational efficiency. The study was designed to collect data related to the barriers to investment in information technology infrastructure library (ITIL) across service and process. The main research method involved interviews in the organizational settings. The framework of balanced scorecard (BSC) was used to collect the data. Results of the multi-case study showed that the ITIL downsides were: 1) incongruence between quality improvement and customer's expectation, 2) inefficiency in meeting customer's needs, 3) conflicts between standardized processes and unanticipated requests, 5) lack of autonomy and calcified learning scope, and 6) people lacking integrative capability.
\end{abstract}

Keywords: Total Quality Management, IT Service, ITIL

\section{INTRODUCTION}

In response to global competitive pressure, service firms are searching for ways to deliver more cost-effective, high-quality IT service, including the principles of total quality management and IT infrastructure library which became ISO20000 since 2005. Information Technology Infrastructure Library or ITIL is one of the quality improvement tools or techniques specially designed for improving IT service and 
creating added value of quality. In short, ITIL helps organizations to meet customer satisfaction through maximizing their information service processes and increasing IT service quality. Worthen (2005), for instance, notes that ITIL helps IT departments improve their service quality, including improvement upon project deliverables and time, resource utilization, a decrease in rework, and providing services that meet business, customer and user demands. Given the attractiveness of the ITIL advantages such as increased productivity, increased efficiency, and reduced downtime, more and more organizations across the world have embraced and implemented ITIL (such as IBM, HP, P\&G, Microsoft and HSBC).

However, is the implementation of the ITIL project truly flawless? In fact, some practitioners have acknowledged concerns over the downsides of ITIL, yet no empirical evidence or explanations on the reasons beyond the barriers were given (see for examples, PR Newswire, 2005; Worthen, 2005; Business Wire, 2006). Although there are many consultants available to offer services in analyzing information systems, processes, employee maturity levels, and gap analyses prior to the ITIL implementation, these services focus only on the mechanism of implementation rather than the efficiency and the impact of ITIL implementation. Lacking information from such an aspect, it is difficult for enterprises to make decisions on how to allocate resources to help implement the quality improvement project and to make better preparations for overcoming any potential barrier that an ITIL project might encounter. Therefore, the goal of the present paper is to highlight the difficulties faced by those who have implemented ITIL on customer services and process.

This paper is organized as the follows. First, the paper will review literature related to quality and quality management theory in order to understand how ITIL can improve IT service quality. The details about ITIL, the applicability of balanced scorecard (BSC) for data collection, and the influence of implementing quality management will be reviewed. Next, the research method and the background information of each case study company will be provided. Third, the research findings and discussions will be presented. Finally, the limitations of the present study and suggestions for further research will be indicated.

\section{WHAT IS ITIL?}

ITIL (Information Technology Infrastructure Library) is a set of best practices originally developed by CCTA (Central Communication and Telecom Agency which is now changed its name as Office of Government Commerce, UK) in 1980s through research into successful organizations and interviews with experts. These practices 
address the organizational structure and skill requirements for the IT organization; the practices are used to help organizations to implement an efficient framework for IT service management, so that firms' resources are maximized and information service quality and customers satisfaction are improved.

Table 1 The Brief Description of Six Major Service Supporting Flows

\begin{tabular}{|c|c|}
\hline Service Desk & $\begin{array}{l}\text { Service desk offers an integrative platform for information users and } \\
\text { service providers. Service desk is also responsible for providing } \\
\text { instructions to fix problems and helping customers to solve their } \\
\text { information-related problems. }\end{array}$ \\
\hline $\begin{array}{l}\text { Incident } \\
\text { Management }\end{array}$ & $\begin{array}{l}\text { This is to provide an incident management flow in order to reduce or } \\
\text { minimize the impact of information service problems. The key of the } \\
\text { incident management flow focuses on how to solve problems quickly } \\
\text { rather than analyzing the cause of problem. }\end{array}$ \\
\hline $\begin{array}{l}\text { Problem } \\
\text { Management }\end{array}$ & $\begin{array}{l}\text { This process is to analyze the causes of abnormality in order to reduce } \\
\text { customers' loss. This will help customers to avoid the same error in the } \\
\text { future. }\end{array}$ \\
\hline $\begin{array}{l}\text { Configuration } \\
\text { Management }\end{array}$ & $\begin{array}{l}\text { This defines all service components, and controls these components so as } \\
\text { to ensure accurate management. Thus, CMDB (configuration } \\
\text { management database) is one of the most important steps of configuration } \\
\text { management. }\end{array}$ \\
\hline $\begin{array}{l}\text { Change } \\
\text { management }\end{array}$ & $\begin{array}{l}\text { This refers to service providers using mechanisms of assessment, check, } \\
\text { implementation, and verification to management all change operations. }\end{array}$ \\
\hline $\begin{array}{l}\text { Release } \\
\text { management }\end{array}$ & $\begin{array}{l}\text { This procedure refers to all the implementation management process that } \\
\text { are required before post-changed service resources or service components } \\
\text { are connected to information systems. }\end{array}$ \\
\hline
\end{tabular}

The framework of ITIL contains seven core aspects, including service support, service delivery, planning to implement service management, security management, ITC infrastructure management, application management, and the business perspective. Among which, service support provides a platform for business, users, and customers to obtain relevant information, and it is the main focus of the core aspects in this paper. The brief description of six major service supporting flows is summarized in Table 1. 


\section{QUALITY AND QUALITY MANAGEMENT}

In the management literature, many theories and frameworks focusing on how to improve product quality in order to increase customer satisfaction have been proposed such as TQM, Six Sigma and ISO (Powell, 1995; Ho et al., 2006). However, service quality is different from product quality, because service quality is an elusive and abstract construct that is difficult to define and measure (Garvin,1983; Zeithaml, 1988; Wakefield and Blodgett, 1999; Bebko, 2000). Quality is customer-oriented and it is to satisfy customers' needs rather than the national standards (Iskikawa, 1985). A narrowly defined quality can be referred to product quality, but a broadly defined quality includes working quality, service quality, information quality, and process quality. Given that the present paper is about information technology, therefore, we will focus on the definition of quality from the standpoint of information technology management. As service products tend to have certain features such as intangibility, inseparability, variability, perish-ability, it is different from tangible products. Service quality can be measured from five aspects: internal qualities, hardware qualities, software qualities, time promptness, and psychological qualities (Juran, 1988).

It is important to note that service quality is different from product quality in its nature, thus it is necessary to include employee qualities, infrastructure qualities, data and information qualities, decision and outcome qualities to have a full understanding of service quality (Rosander, 1985). According to PZB model (also known as the gap model), there are five service quality gaps including customer expectation-management perception gap, management perception-service quality specification gap, service quality specification-service delivery gap, service delivery-external communications gap, and expected service-perceived service gap (Parasuraman, Zeithaml, \& Berry, 1994). Thus, closing the gap between service provided and customer's perception on service quality is crucial to customer satisfaction. All in all, organizations need to take into consideration of customers' perception when setting service quality measurements, since service quality encompasses both expected standards and perceived standards.

\section{THE EFFECT OF IMPLEMENTING QUALITY MANAGEMENT}

In the literature, the effect of implementing quality management projects includes both positive and negative aspects. Implementing a quality project helps a firm to develop service equipment that meets customers' needs so as to obtain customer commitment, increase the efficiency in problem solving and reduce production costs, and improve service quality through collecting, analyzing and disseminating 
information related to service quality improvement etc (Crosby, 1979; Deming, 1988). In contrast, implementing a quality management project could also create some barriers to customer service and process. Table 2 summarizes the barriers resulted from implementing quality improvement projects. From customers' perspective, the implementation of a quality project results in a gap between the quality improved and customers' expectation, as customers believe that a high level of service quality must meet their expectations and special requirements (Deming, 1988; Ravichandran, 1999; Scott, 2005). From the financial perspective, imbalance between the firm's performance and investment can often be found as a result of implementing a quality improvement project (Neal et al., 1995; Soltani et al., 2004). From the internal process perspective, the barrier includes inflexibility of IT infrastructure and lack of efficiency (Pande et al., 2000), time-consuming in the process design and learning new processes, and reduced responsiveness due to too many processes and procedures to follow (Price and Chen, 1993). Finally, the barrier against adopting a quality management project on learning and growth aspect includes employees' resistance and incapability of integrating resources across departments and various quality projects (Hoerl, 1998; Pande et al., 2000; Snee, 2000).

Table 2 Summary of the barriers resulted from implementing quality projects

\begin{tabular}{|c|l|l|}
\hline Item & \multicolumn{2}{|l|}{ Projects } \\
\hline Customer aspect & $\begin{array}{l}\text { ISO9000 } \\
\text { 2005). }\end{array}$ & TQM \\
\hline 2 & $\begin{array}{l}\text { Customer satisfaction cannot be simply improved by IT (Douglas and } \\
\text { Fredendall, 2004). }\end{array}$ & TQM \\
\hline 3 & $\begin{array}{l}\text { The delay in improving customer satisfaction leads to distrust employees } \\
\text { on firms' commitment of quality management (Price and Chen,1993) }\end{array}$ & TQM \\
\hline Financial aspect & $\begin{array}{l}\text { Too much emphasis on problem solving and ignoring the cost of } \\
\text { problem solving (Neal et al., 1995). }\end{array}$ & TQM \\
\hline 2 & $\begin{array}{l}\text { Quality improvement cannot be directly reflected in the revenue (Soltani } \\
\text { et al., 2004). }\end{array}$ & $\begin{array}{l}\text { TQM } \\
\text { Difficult to clearly define the timing of quality improvement (Harry, } \\
\text { 2000). }\end{array}$ \\
\hline
\end{tabular}


Table 2 Summary of the barriers resulted from implementing quality projects (continued)

\begin{tabular}{|c|l|l|}
\hline Item & \multicolumn{2}{|l|}{ Projects } \\
\hline \multicolumn{2}{|c|}{ Process aspect } & TQM \\
\hline 1 & $\begin{array}{l}\text { The consideration of maximizing organizational profits hinders the } \\
\text { willingness of process change (Neal et al., 1995). }\end{array}$ & $\begin{array}{l}\text { Standardized quality process can be inflexible and inefficient (Flynn et } \\
\text { al., 1995; Pande, et al., 2000) }\end{array}$ \\
\hline 3 & $\begin{array}{l}\text { Lack of supporting systems to facilitate process change (Hoerl,1998; } \\
\text { Snee, 2000). }\end{array}$ & $\begin{array}{l}\text { Six Sigma } \\
\text { TQM }\end{array}$ \\
\hline Learning and growth aspect & Sixma \\
\hline 1 & Employees' resistance to change (Price, and Chen,1993). & TQM \\
\hline
\end{tabular}

Source: summarized by the authors

\section{APPLICABILITY OF BSC (BALANCED SCORECARD)}

In 1992, BSC (Balanced Scorecard) was developed by Professor Robert Kaplan at Harvard University and Mr. David Norton who was the CEO at Renaissance Worldwide Strategy Group to assist organizations to clarify their vision and strategy and then translate them into actions. BSC consists of four essential components: the financial perspective, the customer perspective, the internal process, and the learning and growth perspective (originally called innovation and learning). The underlying philosophy of BSC is inspired from learning organization and quality improvement. The basic premise is that only when the indicators of all aspects of an organization are uniformly strong, an organization can sustain its competitive advantage. BSC not only allows managers to assess their past performance but also enables firms to address specific problems to enhance the firm's future performance. The BSC approach can be used to connect a company's strategic objectives to their performance measurements, as BSC enables firms to identify specific measurements that are useful in leading firms to develop their strategic objectives.

Among various management tools devised, BSC has been considered a highly effective tool for helping corporations in their decision making processes. This is because BSC incorporates both financial and non-financial information measures in one report and provides information that cannot be represented by financial measure alone (Kaplan and Norton, 1992). Therefore, BSC is particularly appropriate for measuring the impact on the recent trend in implementing ITIL, as implementing ITIL requires efforts across people, process, and technology (Dubie, 2005). Regarding the 
nature of the quality improvement project (e.g. ITIL), financial indicators alone cannot fully reflect the intangible aspects of outcomes. Therefore, this paper adopts the framework of BSC for data collection, because BSC simultaneously evaluate the financial, customer, internal process and learning and growth aspects that guarantees a comprehensive analysis.

\section{METHODS}

Our research design incorporated a multi-case study on three service-based firms that had implemented ITIL support service management. Based on the literature (see Table 2), we built a semi-structured questionnaire as the instrument to collect data regarding barriers occurred during and after ITIL implementation. Table 3 shows the background information of interviewees. In order to increase the effectiveness of the interview, the questions were mailed to the targeted interviewees prior to the interview. Each interview lasted between one and two hours to gather detailed information related to the influence of ITIL implementation on four perspectives: financial, customer, process, and learning and growth. In addition to the interviews, we also collected archival materials including reports on the process of implementing ITIL, which together enhance validity through triangulation and respondent validation (Mays and Pope, 2000).

Table 3 Background Information of Interviewees

\begin{tabular}{clll}
\hline Interviewees & Firm & \multicolumn{1}{c}{$\begin{array}{c}\text { Position/ } \\
\text { length of service (years) }\end{array}$} & \multicolumn{1}{c}{$\begin{array}{c}\text { Responsibility in ITIL } \\
\text { implementation }\end{array}$} \\
\hline 1 & LGC & Senior consultant/12 & $\begin{array}{l}\text { Project planning and } \\
\text { implementing }\end{array}$ \\
\hline 2 & LGC & System manager/8 & Project user \\
\hline 3 & LGC & Manager of IT dept/15 & Project planning \\
\hline 4 & LGC & System analyst/17 & Project planning \\
\hline 5 & SBK & Manager of IT dept/12 & Project user \\
\hline 6 & SBK & $\begin{array}{l}\text { System supporting } \\
\text { engineer/7 }\end{array}$ & Project user \\
\hline 7 & SBK & Senior consultant/10 & $\begin{array}{l}\text { Project planning and } \\
\text { implementing }\end{array}$ \\
\hline 8 & SBK & Manager of IT dept/12 & Project implementation \\
\hline
\end{tabular}


Table 3 Background Information of Interviewees (continued)

\begin{tabular}{clll}
\hline Interviewees & \multicolumn{1}{c}{ Firm } & \multicolumn{1}{c}{$\begin{array}{c}\text { Position/ } \\
\text { length of service (years) }\end{array}$} & \multicolumn{1}{c}{$\begin{array}{c}\text { Responsibility in ITIL } \\
\text { implementation }\end{array}$} \\
\hline 9 & T-telecom & $\begin{array}{l}\text { Vice director of IT } \\
\text { dept/15 }\end{array}$ & $\begin{array}{l}\text { Project planning and } \\
\text { implementing }\end{array}$ \\
\hline 10 & T-telecom & Senior consultant/14 & $\begin{array}{l}\text { Project planning and } \\
\text { implementing }\end{array}$ \\
\hline 11 & T-telecom & $\begin{array}{l}\text { System supporting } \\
\text { engineer /8 }\end{array}$ & Project user \\
\hline \multirow{2}{*}{12} & T-telecom & $\begin{array}{l}\text { Manager of customer } \\
\text { service/12 }\end{array}$ & Project user \\
\hline
\end{tabular}

\section{BACKGROUND INFORMATION OF CASE STUDY COMPANIES}

The companies included in this study are a state-owned institute (LGC), one bank (SBK), and one telecom (T-telecom). These companies share similar characteristics broadly defined in terms of their operation nature. All three firms have a company history of at least 20 years. They all operate in service industry based on service quality and efficiency. All three case study firms have introduced IT infrastructure library to monitor and improve call center performance in order to increase customer satisfaction.

LGC serves as a portal between the government and the public. It provides regulation-related information to the public and, at the same, gathers and delivers citizens' problems and complaints to the government offices. LGC implemented ITIL' service support system in 450 service points in 2006. This system is built to offer more than 100 call center staff and IT engineers a complete IT service support process. As a result, LGC can establish a configuration management database which enables the institute to record, follow-up and check reports of customer's complaints.

SBK is a subsidiary of a large foreign-owned bank. The company currently hires over 1,000 people. SBK has outsourced its computer systems to a firm which is well-known for its consulting and integration, managed service, and outsourcing service. The outsourced firms employed ITIL service support management process for SBK's computer systems.

T-telecom is one of the leading telecoms in the telecommunication industry. It is the first privatized telecom that obtains the license of operating national-wide GSM1800 systems and it is also the first firm promoting 3G mobile communication services of WCDMA systems. T-telecom also provides a wide range of information communication services such as $2 \mathrm{G}, 3 \mathrm{G}$ and land line; it has more than seven million 
customers. The company has implemented the ITIL since 2001. Customer service center provides front line services to customers' calls, but when the problem cannot be solved by the customer service center then the call will be passed to ITIL support service processes.

\section{FINDINGS AND DISCUSSIONS}

Generally speaking, there is a close relationship between the customer service department and a firm's performance. In order to enhance the productivity and efficiency in the customer service department, the three firms have implemented the service support system of ITIL as they faced a rapid increase in demand of customer service. The purpose of implementing ITIL strongly resembles to what is advocated in the TQM philosophy-- embedding awareness of quality in IT service process, and which requires the involvement of staff from customer service department and IT service support department in continuous quality improvement in order to maximize the overall efficiency and effectiveness.

The motivation behind this was to establish a database which enabled front line staff to record customers' problems and then passed them to IT supporting staff, thus the responsiveness to customers' needs was increased. A further motivation was that if the simple problems could be solved by the customer service department, then the professional IT engineers might have more time for IT related problems, thus increasing the speed of problem solving as a whole.

All three case study companies set up some key performance indicators in service level management (SLM) for call center to guarantee levels of service to be complied with, thereby demonstrating service consistency, delivery performance, and service durability. However, some barriers of various nature have overshadowed the promotion of ITIL or the attempt to increase the efficiency in IT service. Table 4 summarizes the barriers occurred during and after ITIL implementation. Table 5 shows the relationship between barriers and four BSC dimensions: financial, customer, process and learning/growth.

From the customer's perspective, the barriers lie mainly in the fact that there is incongruence between IT quality improvement in ITIL principle and in customer's perception. According to ITIL, the objective of IT quality management is to record customers' problems and the corresponding solutions into a database so that the solutions can be retrieved quickly from the database when the same problem occurs again. Following this logic, problem solving time shall be reduced so that customer satisfaction shall be enhanced. However in reality, most customers prefer direct 
communication with IT service supporting engineers to customer service staff. Many IT service quality initiatives have been adopted by the call center in order to maximize their customer satisfaction with their service. The problem is that ITIL program focuses on IT related problem solving and the interaction with customer after problems occurred, but the customer expects to have a good service quality starting from having a direct contact with the firm rather than after problem occurred (Douglas, and Fredendall, 2004; Scott, 2005). This implies that simply focusing on process quality and overlooking product quality, which refers to the design of software and its output such as documents, program codes or testing methods, is not enough to satisfy customer's expectation (Deutsch and Willis,1988).

In addition, customer satisfaction is not solely dependent on the speed of problem solving but also on customers' perception about service quality improvement (Parasuraman et al., 1994; Ravichandran, 1999). For instance, a customer encounters a slow connection in her use of internet, so she makes a call to the customer service department to complain. Given the implementation of ITIL, the front line staff answers the call politely and records the problem much quicker than it used to, but the customer will not be satisfied as the problem of slow connection has not been immediately solved yet.

However, the subjective perception is difficult to measure, so the key performance index (KPI) of service level management is not suitable for the measurement. Moreover, the other barrier is that the call center staff was incapable of dealing with customers' special demands after following the best IT practices. "Customers often cannot clearly express their service needs and do not know the corresponding performance requirements". Thus, at times the customer service department staff do not know how to assign a specific customer to a particular IT service category.

Regarding the financial perspective, large investments have been put into extra training courses, seminars, taking certifications, internal process maturity assessments, cross-departmental communications, tool exploratory trainings, the use of management reports, and educating IT service related quality concepts, as IITL offers a set of best practices but does not give advices on how to actually implement the best practices (Worthen, 2005).

Thus, each firm has to design individual ITIL practices in accordance with its business objectives, which is different from traditional large scale projects. In principle, these investments were supposed to increase employees' skills and knowledge so as to improve IT service, reduce downtime and error costs, and increase 
firm performance. But in practice, the direct link between increased efficiency in IT service and firm performance was difficult to be identified in short-run, due to the needs of long term learning about new quality service processes. Budgets that had been put into employee training and other internal process improvement are easy to measure, but the direct outcomes generated from enhanced quality, increased service level and organizational flexibility are hard to measure.

It is also true that the improvement on the level of service quality and increased flexibility in organizations is difficult to measure from a financial perspective, and therefore the immeasurable nature of quality improvement, in terms of financial outcomes, could lead to the misperception of no return on investment (Soltani et al., 2004). In addition, the companies in the case study expected that, after implementing ITIL, employees could follow the standard problem solving procedures, leading to enhanced employees' satisfaction. However, some employees prefer more autonomy at work to formalized standard processes in dealing with IT related problems and, as a result, employee turnover rate was slightly increased due to incapability of adapting to the new working processes. This is where the imbalance between the investment in ITIL and direct performance link has casted some doubts in the three companies to devoting more investments in ITIL.

Regarding the process aspect of implementing ITIL, most interviewees felt that implementing ITIL simplified the existing processes and met quality requirements which led to maximizing firms' resources, although it, at the same time, required more time in checking and designing new processes. However, the design of the ITIL process was considered neither flexible nor effective in response to the change of business environment. According to ITIL, a firm needs to set up various processes in accordance with the level of customers, type of services, and the steps of solving problems prior to the implementation of ITIL service support program for the frontline staff to follow, these processes may not have enough coverage in meeting different customers' needs.

Thus, the predefined service processes require some changes, but the change of service processes is usually time-consuming. As a service support process usually involves cross functional cooperation and collaboration, changing service support process means re-coordination between front line staff and IT supporting staff, and re-integrating relevant resources, process, tool flexibility and customer requirements prior to the design of ITIL process, thus reducing the responsiveness to the change of business environment. 
Besides, conflicts between different interests groups often occur after implementing the ITIL service support program. The implementation of ITIL required long term battles in terms of cross departmental negotiation, processes scrutiny and many changes in program designs, but the consideration on the cost which might be needed to increase in newly designed processes often forced the service support processes to keep at minimum changes or to be postponed. Therefore, it was difficult to carry out newly designed service processes and consequently, affected customers' trust in firm's willingness to quality improvement. This finding is consistent with prior research (see for examples, Flynn et al., 1995; Hoerl, 1998; Pande et al., 2000; Snee, 2000) in that inflexibility IT infrastructure had an impact on firm's performance and competitive advantage.

Moreover, it was difficult to assess the immediate effect of ITIL on the continuous process of improvement, because of the additional work required to record customer problems and follow-ups. Furthermore, the implementation of ITIL is not a one time shot, it requires continuous improvement in organizational process. Organizations that implemented ITIL need to put resources into cross-functional integration and coordination, process checking, IT program changes, and updating both software and hardwires etc. Though when the management of these processes are not in urgent need, it still needs many people and resources to support. As the difficulty in measuring the immediate influence of IT service quality improvement on organizational performance, management teams seem to be reluctant to approve further investment in supporting continuous process improvement, which, consequently, affects customers' perception on the firms' service durability and responsibility.

As for the learning and growth aspect, employees' commitment serves as another barrier. Although having predefined working procedures may reduce employees' frustration in dealing with complicated IT problems and therefore improves employees' satisfaction, this does not increase employees' commitment.

Employees, in contrast, expressed their worries about the replacement of IT infrastructure on standardized problem-solving processes and skills, although such an influence would not happen in short term before the ITIL project reached a mature stage. "The higher the degree of standardized working procedures, the more likely the replace-ability of employee skills". Although implementing ITIL means more training, the standardized working procedures seems to have narrowed down the scope of learning, and solidify employees' thinking to a certain range. For some IT service support staff, although training may enhance employees' knowledge and skills, they 
tend to take individual responsibility in solving problems rather than working as a team. "As long as the problem is not occurred in my responsible area, even if I know the solution I would not help because I would not get more money." "Certain areas of experts may provide more help than us such as external consultants, those who possess ITIL certificates, system integration engineers, and those who experienced in leading large projects such as PMP certificate”.

Moreover, a common reason for the IT staff's resistance to the idea of ITIL is its perceived unfairness. For the majority of interviewees, recording the detail of problem solving into a database means losing their advantage. "You spend lots of time finding solutions to solve a problem, but when you record knowledge into the knowledge-base within the firm, you, at the same time, lose your advantage." Although the implementation of ITIL takes similar philosophy of TQM in its continuous improvement and team work, without a proper reward system, the collaboration between different departments seems to have lots of room for improvement. "Helping colleagues to solve problem would not help us to get more bonuses, so we just need to take responsibility in our own work area”. In addition, it appears that the lack of close collaboration between IT service support department and customer service department serves as another barrier. "As we are trained to take responsibility in a certain job specification, we sometimes find difficulties in understanding IT service support process at integrated basis for IT service support techniques, development methods, and problem solving skills."

Table 4 Summarized result of barriers occurred during and after implementing ITIL based on four BSC aspects

\begin{tabular}{|c|c|c|c|c|c|}
\hline & Barrier of Implementing ITIL & Financial & Customer & $\begin{array}{l}\text { Internal } \\
\text { process }\end{array}$ & $\begin{array}{l}\text { Learning/ } \\
\text { growth }\end{array}$ \\
\hline 1 & $\begin{array}{l}\text { Dissatisfied customers due to the } \\
\text { gap between the degree of } \\
\text { improved service quality and } \\
\text { customers' perception }\end{array}$ & & V & & \\
\hline 2 & $\begin{array}{l}\text { Unable to satisfy customers' } \\
\text { specific needs in time }\end{array}$ & & V & & \\
\hline 3 & $\begin{array}{l}\text { Extra costs occurred in education } \\
\text { and management }\end{array}$ & V & & & \\
\hline 4 & $\begin{array}{l}\text { Time lag between investment in } \\
\text { ITIL project and performance } \\
\text { outcome }\end{array}$ & V & & V & \\
\hline
\end{tabular}


Table 4 Summarized result of barriers occurred during and after implementing ITIL based on four BSC aspects (continued)

\begin{tabular}{|c|l|c|c|c|c|}
\hline & \multicolumn{1}{|c|}{ Barrier of Implementing ITIL } & Financial & Customer & $\begin{array}{l}\text { Internal } \\
\text { process }\end{array}$ & $\begin{array}{l}\text { Learning/ } \\
\text { growth }\end{array}$ \\
\hline 5 & $\begin{array}{l}\text { Conflicts between urgent needs } \\
\text { for quality improvement and cost } \\
\text { consideration }\end{array}$ & $\mathrm{V}$ & & $\mathrm{V}$ & $\mathrm{V}$ \\
\hline 6 & Difficulties in implementation & & & & $\mathrm{V}$ \\
\hline 7 & Employee resistance & & & & $\mathrm{V}$ \\
\hline 8 & Lack of integration ability & & & & \\
\hline
\end{tabular}

To sum up, from the above mentioned barriers occurred after implementing ITIL, it can be seen that the barriers not only have an impact on the firm, but also on customers, the call center and IT service staff, and employees in other departments. This implies that it is not a simple linkage between ITIL adoption and increased service quality, increased adding value, and increased customer satisfaction. This is due to the fact that ITIL improves certain aspects of service quality (i.e. visibility and responsiveness), but not the others (i.e. reliability, durableness and sympathy) that tend to be defined by customers' perception and intuition (Parasuraman et al., 1994). In addition, through the analysis of the barriers based on the four dimensions in BSC, it can be seen that each dimension of BSC is interrelated (as seen in Table 5). Employees' skills affect process quality and process cycle, and the internal processes could affect customers' commitment which influences firms' performance. Therefore, when adopting a quality improvement project, managers should be aware of the wide spectrum of impact and should not only focus on a single aspect like the costs of implementation. 
Table 5 the relationship between each barrier and BSC dimensions

\begin{tabular}{|l|l|l|}
\hline \multicolumn{3}{|c|}{ Financial aspect } \\
\hline Extra costs occurred in education and \\
management \\
Unclear relationship between ITIL project and \\
return on investment
\end{tabular}

\section{CONCLUSION AND LIMITATIONS}

The ever-increasing customer demands and the heightened global competition necessitate a re-examination of the role that improved IT service process plays in creating business value and shaping firm's competitive capability (Weill and Broadbent, 1998). In response to the competitive pressure, many firms devoted lots of resources into information technology to enhance customer satisfaction, especially the typical service firms such as those studied in this paper. In the case study firms, there have been attempts to enhance customer satisfaction through increasing efficiency in IT service support process. But the success was limited for various 
reasons, as summarized in Table 4.

Successful implementation of ITIL requires top management commitment to information technology, a greater sense of co-operation and involvement of both call center staff and IT support staff, and an attitude change from everybody that is not my job to what I can do to help (Price and Chen, 1993; Weill and Broadbent, 1998; Ravichandran, 1999). Yet, all these essential ingredients have been missing in the three case study companies. The somewhat immeasurable nature of the effect of investment in ITIL on firm's performance has led to the reluctance to support long-term IT process changes and continuous IT improvement. For instance, in SBK, the top management assumed that the large investment in ITIL should bring significant increase in firms' performance. However, after a while, the outcome was less than satisfied. Afterwards, the firm tends to take more consideration on keeping cost-down than supporting necessary training and changes in organizational process.

In all three case study companies, if there was any practice of TQM philosophy and team working between the call center and IT service support staff, this practice only existed informally, based on sound personal relationship rather than through any formal implementation of the ITIL. With entrenched departmental barriers and employees' resistance, managements have not forced the issue further. In the day-to-day work, the people across different work units are far more difficult to have mutual support formalized or encouraged. This might due to the conflict between efficient responsiveness and standardized IT service supporting flow. Moreover, customer satisfaction does not simply depend on process quality but also product quality, however; the aspect of product quality seems to have been overlooked in ITIL.

Evidence from this study suggests that implementing ITIL is by no means an easy task, which is heavily burdened by some barriers such as those found in the three case study companies. These barriers will be even less surmountable without a strong backing from the top management, which has been largely lacking in these three firms. Also, the communications between both internal and external customers, designing reward systems that encouraging the adoption of the quality project and crating the culture that emphasizing continuous improvement are all crucial.

The generalizability of this study is limited for at least two reasons. First of all, the research sample is rather small because only three companies were studied. Second, the study focused on the specific service-based industry and it is unknown whether similar barriers would also exist in other industry. Due to that the implementation of ITIL program is just at its infancy, it is not plausible to find more 
companies that have already adopted ITIL. In the near future, when the adoption has become more popular, it would be interesting to do cross industrial research to know whether or not the industrial factors can affect the outcome of ITIL adoption. Moreover, focusing on industrial life cycle as a variable for examining the impact of ITIL might also shed the light on the information management literature, because firms with different maturity levels could have different benefits and impacts from the adoption of ITIL.

\section{REFERENCES}

Bebko, C.P. (2000). Service intangibility and its impact on consumer expectations of service quality, Journal of Services Marketing, 14(1), 9-26.

Evergreen Systems, Inc. announces second annual ITIL benchmark study; company identifies common pitfalls and provides best practice recommendations. (2006, March, 1). Business Wire. 1-3.

Crosby, P.B. (1979). Quality is free. New York: MacGraw-Hill Book Co..

Deming, W.E. (1988). Out of the crisis. Cambridge, MA: MIT Centre for Advanced Engineering Study.

Deutsch, M.S. \& Willis, R.R. (1988). Software Quality Engineering: A Total Technical and Management Approach. New York: Prentice Hill, Inc.

Douglas, T. J. \& Fredendall, L. D. (2004). Evaluating the Deming management model of total quality in services, Decision Science, 35(3), 393.

Dubie, D. (2005). IT pros share their tales of making ITIL work, Network World, 22 (38), 8-9.

Flynn, B.B., Schroeder, R.G. \& Sakakibara, S. (1995). The impact of quality management practices on performance and competitive advantage, Decision Science, 26(5), 659-691.

Garvin, D.A. (1983). Quality on line, Harvard Business Review, Sept-Oct, 65-75.

Harry, M. J. (2000). Abatement of business risk is key to six sigma, Quality Progress.

Ho, L-H. \& Chuang, C-C. (2006) A study of implementing six sigma quality management system in government agencies for raising service quality, Journal of American Academy of Business, 10(1), 167-173.

Hoerl, R.W. (1998). Six sigma and the future of the quality profession, Quality Progress, 31(6), 35-42.

Iskikawa, K. (1985). What is total quality control? The Japanese way. Englewood Cliffs, NJ: Prentice-Hall Inc.. 
Juran, J.M. (1988). Juran's quality control handbook. (4 ${ }^{\text {th }}$ ed.). New York: MacGraw-Hill Book Co..

Kaplan, R. S. \& Norton, D. P. (1992). The balanced scorecard-measures that drive performance, Harvard Business Review, 70(1), 71-79.

Mays, N. \& Pope, C. (2000). Assessing quality in qualitative research, British Medical Journal, 320, 50-52.

Neal, J. A., Tromley, C. L. Lopez, E. \& Russell., J. (1995). From incremental change to retrofit: creating high performance work systems, The Academy of Management Executive, 9(1), 42-55.

Pande, P.S., Neuman, R. \& Cavanagh, R. (2000). The six sigma way: how GE, Motorola, and other top companies are honing their performance. New York: McGraw Hill.

Parasuraman, A., Zeithaml, V.A. \& Berry, L.L. (1994). A conceptual model of service quality and its implications for future research, Journal of Marketing, 58, 111-124.

Powell, T.C. (1995) Total quality management as competitive advantage: a review and empirical study, Strategic Management Journal, 16(1), 15-37.

Price, M.J. \& Chen, E.E. (1993). Total quality management in a small, high-technology company, California Management Review, 35, 96-117.

PR Newswire. (2005). Opalis describes top three reasons for ITIL implementation failures at Pink Elephant ITIL case studies symposium, PR Wire, Aug, 1-2.

Ravichandran, A.R. (1999). Total quality management in information systems development: key constructs and relationships, Journal of Management Information Systems, 16(3), 119-155.

Rosander, A.C (1985). Application of quality control in the service industries. New York: ASQC Quality Press.

Scott, J. (2005). ISO 9000 in service: the good, the bad and the ugly, Quality Progress, 38(9), 42-48.

Snee, R.D. (2000). Impact of six sigma on quality engineering, Quality Engineering, 12 (3), ix-xiv.

Soltani, E., Van de Meer, R.B. \& Williams, M.T. (2004). Case study: have TQM organizations adjusted their performance management systems? A study of UK-based TQM-driven organizations”, Total Quality Management, 15(8), 1069-1091.

Wakefield, K.L. \& Bodgett, J.G. (1999). Customer response to intangible and tangible service factors, Psychology \& Marketing, 16(1), 51-68. 
Weill, P. \& Broadbent, M. (1998). Leveraging the New Infrastructure. Boston: Massachusetts: Harvard Business School Press.

Worthen, B. (2005). ITIL Power: why the IT infrastructure library is becoming the most popular process framework for running IT in America, and what is can do for you, $C I O, 18(22), 1-5$.

Zeithaml, V.A. (1988). Consumer perceptions of price quality and value: a means-end model and synthesis of evidence, Journal of Marketing, 52(3), 2-22. 
